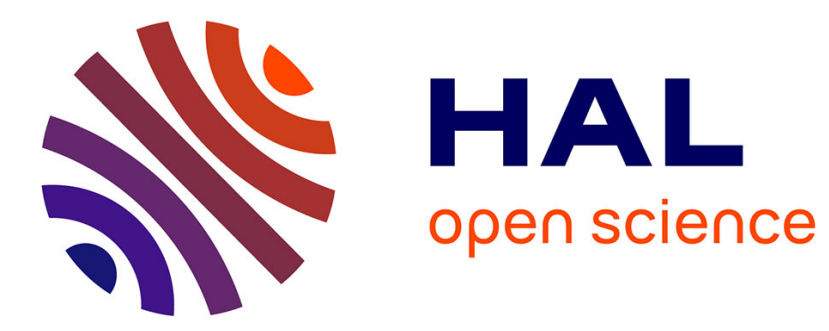

\title{
Reading Early Music Today: Between Reenactment and New Technologies
}

Julien Ferrando

\section{To cite this version:}

Julien Ferrando. Reading Early Music Today: Between Reenactment and New Technologies. 13th International Symposium on Computer Music Multidisciplinary Research, Sep 2017, Matosinhos, Portugal. hal-01794806

\section{HAL Id: hal-01794806 https://hal.science/hal-01794806}

Submitted on 17 May 2018

HAL is a multi-disciplinary open access archive for the deposit and dissemination of scientific research documents, whether they are published or not. The documents may come from teaching and research institutions in France or abroad, or from public or private research centers.
L'archive ouverte pluridisciplinaire HAL, est destinée au dépôt et à la diffusion de documents scientifiques de niveau recherche, publiés ou non, émanant des établissements d'enseignement et de recherche français ou étrangers, des laboratoires publics ou privés. 


\title{
Reading Early Music Today: Between Reenactment and New Technologies
}

\author{
Julien Ferrando \\ Aix Marseille University \\ CNRS, PRISM "Perception, Représentations, Image, Son, Musique" \\ Marseille, France \\ julien.ferrando@univ-amu.fr
}

\begin{abstract}
Since the revival of Historically Informed Performance in the 1960s, the interpretation of Early Music has continuously raised questions many of which remain unanswered. Nevertheless, understanding of earlier practice continues to grow and performers have long surpassed the strict historical urtext approach that initially prevailed, largely due to the growing body of evidence that instrumentalists of earlier times relied heavily on aurally transmitted improvised musical traditions, which can only be re-imagined today. The modern musician must also improvise in order to reconstitute or re-invent missing elements belonging to a long-forgotten tradition. From a philosophical point of view, therefore, the performance of early music today is closely related to hermeneutics, and the multiple questions involved in the interpretative process.
\end{abstract}

Keywords: Early music, Re-enactment, Re-creation, Interpretation.

\section{Introduction}

I propose here to discuss issues concerning the performance of Early Music today, in order to present the dialectic that lies between historically informed performance (HIP) and re-creation, or between a faithful reconstruction and a creative act. These considerations will lead to the presentation of Musical Performance in Historical Soundscape (MPHS) that is today realizable with the help of new technologies (binaural restitution in particular). To do so, I will first observe how the concept of musical heritage has evolved in our century, and then present an approach where a new insight on this heritage can foster creative musical ideas. I will talk here as a musicologist, but also as a practitioner specialized in early keyboards (organetto, clavicytherium and harpsichord).

\section{The necessity to rebuild history}

The problem of re-interpreting the past was addressed in particular in the first half of the 19th century. Productions inherited from History were named antique or primitive and, most of the time, were considered at best as interesting curiosities. With the exception of Gregorian chant (from the Solesme school), Music 
of the Middle Ages, similarly, was considered as exotic. Major academic institutions such as Paris Conservatoire or Schola Cantorum had a strong influence on musical aesthetic values. Tonal harmony, with its strict rules, constituted the foundations of any apprenticeship of musical composition. Amédée Gastoué is a perfect example. Organist and well-known teacher at the Schola Cantorum, he occupied a prominent role in the exhumation of medieval musical sources, and was also a vitriolic critic towards contrapuntal techniques used in the 14th Century in Avignon. Here are few examples extract from an academic article about the music of the Apt Manuscript (one of the major sources of Fourteenth Century Polyphonic music), published in 1904 in the Rivista Musicale Italiana:

"It would be vain to transcribe the rest of the piece since it would sound too primitive to our refined ears (...)This might seem laborious but I believe it is good to display few extracts of this crude style, that will later find its accomplishment in Josquin." [1, p. 275-276]

This quote present history as a goal oriented process, implicitly founded upon a theory of a linear progression in the arts, or simplistic social and artistic evolutionist principals. Such views presuppose that archaic societies were governed by superstitious thinking, and evolved towards an implicit progress guided by modern scientific laws. An influence of philosophical positivism can be perceived in this approach to musical research. These judgments betray advanced forms of ethnocentrism, as well as an anthropologic view based on simplified classifications, presupposing value judgments, and an arbitrary superiority of the new over former societies. Chronology is therefore profoundly misread in such conceptions, and hijacked as a means to classify works of art in successive and coherent periods of History. Unfortunately, such chronologic classification often let down the anthropologic reality of the works themselves.

\section{Re-writing as a means to re-interpret the past}

At the end of the 19th Century, in spite of increasing interest in Baroque and Renaissance music, the concept of historically informed performance - or replacing a repertoire in its context - is not yet considered a legitimate approach. Vincent D'Indy exhumes and rewrites Monteverdi's operas (among which the Orfeo). Around 1904, Debussy and Ravel found French baroque music a major source of inspiration. The Tombeau de Couperin, for instance, is a stylistic hommage to the court of Louis XIV, with clear references to dance suites (Prelude, Menuet, Rigaudon, Forlane...). However, beyond those references to ancient form, he could only use a parodic tone in order to make his own a language that was far too remote from his time, since very little was known about the organology of harpsichord at that time. Ravel therefore adapts and uses as a major source of inspiration what he imagines characteristic of Couperin's style $[2$, p. $54,106,246]$. In this process of adaptation, Ravel recombines elements of a remote era with his own compositional taste and techniques. He uses ornaments in his own way, adopts the flow of baroque phrasing with a harmonic language 
which will become characteristic of his style. With his singular relationship towards tradition, Ravel opens new perspectives for the Groupe des Six. Among them, Poulenc is perhaps the main instigator of this tendency ${ }^{1}[4]$. Around the same time, Wanda Landowska [5] starts pioneer research works on instruments that initiated a whole rediscovery of Baroque keyboard music, and her collaboration with Pleyel makes possible the reconstitution of the first harpsichords [6, p. 425]. Such instruments were already well-known at that time, however, harpsichords were conceived as plucked-strings pianos rather than copies of historical instruments. The goal here was to adapt modern instrument rather than reproduce replicas of the historical models. In this sense it is reminiscent of the way Ravel absorbs a music of the past that he imagines in order to create something new: Baroque music is in this case readjusted so as to become a major source of inspiration, thus provoking experimentation and creation. The work of Wanda Landowska even prompted composers of the time to write for modern harpsichord [7], and this how the Polish-French keyboard player initiated the composition of Francis Poulenc's Concerto Champêtre, the first harpsichord concerto of modern times.

\section{Re-reading early music as a neoclassic act?}

The works of Poulenc, Ravel, and all composers using materials inspired by modal Gregorian Chant, were classified as Neo-Classical in their time. This term, when used by a progressivist such as Varèse, was derogatory [8, p. 178-180]. Nevertheless I propose here that such an issue was not addressed correctly at that time. Beyond a mere taxonomy by time period and style, writing in a language inspired from the past should not always be understood as a regressive act, but rather as a means to integrate references from the past, engage with tradition, in order to place them in a contemporary perspective. Henri Meschonnic [9] proposes to speak of a modern unity, and shows that elements can ressemble each other in such a way that can all be conceived as related to one unique kernel. A modern unity, with a sense of a one-way History, endeavors to find, in avant-gardes, structural ressemblances, so as to group them around few types, and extract meaning from them. The notion of convergence is here of particular relevance: reject of difference are classified as one further category of the whole: Compulsion of convergence, compulsion of unity, wordplay of the singular, a stance of universality [8, p. 56-58]. This linear conception of time also reveals a conception of music as a vertical construction, or purely architectural, in which History would therefore not anymore be understood as filtered by religious thought. Michel Faure says:

"Designation such as gothic, baroque, rococo, impressionist, cubist, applied to certain forms of art, were initially highly pejorative, but later acquired their dignified signification" [8, p. 180].

\footnotetext{
${ }^{1}$ The CD "Poulenc au Moyen Âge", by the French ensembles Mescolanza and Les Zippoventilés illustrates this tendency [3].
} 
Novelty is often observed with fear. The notion of Neoclassicism itself denotes the insight of a composer for understanding music as necessarily overstepping tradition. Under this assertion Neoclassicism can only be pejorative. However, beyond progressivist considerations, a growing interest in Early Music will entail a desire for the discovery of an exhaustive unknown heritage [10]. Such aspirations for rediscovery of the past see their first peak in the 1950s, which musicians such as Nicolaus Harnoncourt, Ralph Kirkpatrick and Gustav Leohnardt.

\section{Rebuilding the musical gesture: an attempt to magnify heritage?}

Approaching an ancient musical document requires several steps in order to surpass the mere historical framework. The interpreter should aim for a re-creation, a philological approach that involves a return to the source, itself a transcription of an expunged and re-interpreted reality ${ }^{2}$. The interpreter also seeks a hermeneutical approach, understanding the work as a document, eventually leading to the elaboration of musical gestures and sounds. The same applies to the reconstructed musical instrument: a "monument" which is necessarily derived from an interpretation of the factor and his practices. Thus every single aspect of an interpretation participate to the elaboration of the work: recording techniques, organology and performance all contribute to the co-authorship of the work [11, p. 31-32]. Since the beginning of the 21st century, economic realities have led early music artists not to produce only "historical" programs, but also performances that offer singularity and originality in their contemporary rereading. Encounters and interactions between artists enable new redeployment of the work. Another major aspect in this reflection concerns the techniques of sound and image taking. A very special experience developed in the late eighties, with the arrival of digital. Labels such as Astrée Auvidis, Arcana, or Harmonia Mundi have developed an editorial singularity in the way to capture the musical reality of the performers and in the choice of microphones. Today multi-micro systems, multitrack editing, high-resolution recording and artificial sound environments open the way to a new way of conceiving the capture and publication of these productions.

\footnotetext{
${ }^{2}$ I refer here to the interpretation of Le Bourgeois Gentilhomme staged by Benjamin Lazar and interpreted by Le Poème Harmonique. In search of a form of reenactment, the piece is reconstituted in all its dimensions, which also implies for instance the lightings of the time, made of candles. The artists played with shadows and light in an expressive way, which has only been possible through their to attempt to reconstruct and understand the work. The Reconstitution of the diction by Eugene Green also, according to the director Benjamin Lazar, proposed new forms of interpretations, and La Comédie franse. The work as a whole cannot be fully grasped when omitting the musical part, which is crucial to its integrity (http://fresques.ina.fr/en-scenes/fiche-media/Scenes00285/lebourgeois-gentilhomme-mis-en-scene-par-benjamin-lazar-au-theatre-l-apostrophede-pontoise.html).
} 
Discoveries in art history and iconography made possible the (re)production of genuine instruments from representation engraved on stones or manuscripts. These crucial research works and practices enabled reflexions on sound ? or sonic material-, timbre, and opened new fields in organology. For instance, bowed vielas of first medieval ensembles resembled fiddle-violins, but during the 1980s, French luthier Christian Rault called into question the presence of the soundpost (âme in French) in the resonance chamber of the instrument. Playing techniques were subsequently deduced from gut strings, bows adjustments, and representations of musicians playing (The recording Mille Bonjours (Alpha [15]), by the french ensemble Diabolus in Musica is a good exemple of such creative research processes). In this sense, an interpreter like Nicolaus Harnoncourt becomes much more than a mere executant. The skills of the musician in his case encompass knowledge in history, a philology, and music anthropology. His aim consists in recontextualizing the work, with rebuilt instruments which increasingly resemble to the ones present in museum collections [12, p. 42-60]. Harnoncourt therefore adresses the complex issue of interpretation through an understanding of the contextual environment of the work. It is a form of historical truth that is at stake in this case. Working on original manuscripts inevitably draws attention to the concept of faithfulness when interpreting a piece of music. This stage of the research process has the great advantage to guide a creative interpretation with essential notions of organology, notation, and improvisation, thus avoiding misreading in transcriptions, or giving access for instance to the reenactment of improvisatory skills through the study of rules expounded in the treatises. This practice became little by little caracteristic of early music studies. Oral tradition takes an important role in this domain, since any many cases, the score is only a canvas into which musical practices can be inserted [12, p. 159].

\section{Is early music a space for creation?}

If we consider that the problem is not to put ourselves in the timeline of a tradition, but rather to consider productions of the past as a way of being in History constantly rebuilt by interpretation [13, p. 127-128], Early Music becomes therefore an object of creation. Then, it does not have a truth-in-itself, but gives to each interpreter a range of possibilities to explore. Contribution of Early Music performers has opened minds regarding the need of a re-contextualizated work. However, nowadays, the historical context can be surpassed, beyond a simple reconstitution on old instruments. For example, we can see some pianists playing today Bach, Couperin, or Rameau's music, acknowledging proposals of interpreters such as Scott Ross, Gustav Leonhardt, Tom Koopman, Muray Perahia or Alexandre Tharaud, who have changed interpretation, ornamental quality and tone color. The idea is not to sound like a harpsichord, but simply to take into account this tradition of interpretation, in order to re-create a work on their instrument. The purpose of this re-creation is to cultivate some awareness about the gap that lays in each musical work, between its historical reality and its 
contemporary interpretative reality. Consequently, today, for a performer, two conceptions of Early Music coexist and complement each other:

- Decyphering the sources, collecting data, and interpret them in order to gather a maximum of evidences informing about the context of the work, in order to attempt attempt a re-creation or re-enactment.

- Considering this first step as preliminary research, or as a basis for a creation, a important part of the work still remains hypothetic, and require creative imagination, to write, improvise, perform, and adapt results to the adequate production context.

This concept of re-enactment - what was described above as the first step emerges from the 1960s, but it presents a keen interest in the context of medieval festivals since the last ten years, with the emergence of multiple reconstructions of historical events or past traditions. Today, many of these festivals involve a sort of popular collective construction of lost traditions. As Aline Caillet says, living and reincarnating History, - reenacting - helps to build collective History in individual stories, by re-engaging them in present time. Whether for re-enactors or artists, it is an attempt to make present an experience of past. As a contemporary scene, its presence here and now is also a way of affirming that History is never gone or resolved. Beyond the mere cliche of a troubadour in a costume, this definition perfectly fits with my approach to Early Music interpretation today, which goes hand in hand with notions of philology, organology, repertoire reconstitution, and perspectives with Art History [14]. This interpretation is nevertheless always conceived as an experience taking place in the present, and therefore as a contemporary artistic attempt. As an example illustrating this idea, I will mention a project where I was involved with the French ensemble Diabolus in Musica. In 2004, the harpsichord maker David Boinnard was asked to recreate a keyboard instrument of the fifteenth century, whose original is in the collection of the Royal College of Music in London. The project was a musical program consisting of Guillaume Dufay songs combined with the projection of an collection of paintings by Jean Fouquet. This project led to a series of concerts and a CD produced in 2007 by Alpha [15]. This program was therefore the pretext to attribute a particular repertoire to this instrument. I have now acquired a great familiarity with this instrument, and experimented with the size of feathers that suits me, so as to facilitate the dexterity shown in the keyboard repertoire of that time. However, because of the string's arrangement, the instrument can be seen as a sort of keyboard harp. I have therefore proposed a string pinching technique, as an alternative to the plucked strings of the keyboard. This attempt led to a rewriting of a keyboard piece of the 15th century: Ein vroulein edel von naturen. ${ }^{3}$ The piece opens with an improvisation in the mode that is not necessarily historic but rather deduced or felt. This interpretation therefore allowed a form of rewriting, or recycling of an existing material. For the second concept, which consists in using existing repertoires for recreation and emergence of new musical languages, we will give two examples:

\footnotetext{
${ }^{3}$ https://www.youtube.com/watch?v $={ }_{J} d f k_{x} O z T c$
} 
- A medieval chant of Martin Codax (A Galician troubadour) revisited by two musicians of the french ensemble Le Poème Harmonique: Claire Lefilliâtre et Joel Grare (of which the recording is unavailable).

- An improvisation/encounter between prepared piano and medieval portative organ by Nathalie Negro and myself. ${ }^{4}$

\section{Avignon 3D: The reconstruction of ancient musical practices}

I would like to conclude by evoking a final point linked to the notion of sounding space. It is clear that sound technology and its spatial representation have recently made huge progress with respect to digital technologies. More recently binaural perception has, thanks to the works made at IRCAM and also at PRISM (AMU-CNRS), enabled to open a research field that we would like to take into account in order to provide new ways of listening to ancient music in a 3D real-time environment:

- Virtually reconstitute both sensory and sonic characteristics of a historical monument, hotspot of musical creation.

- Enable artists to confront, while practicing in a recoding studio, their musical repertoire with the original acoustics associated to a chosen edifice (St Mark's Basilica, or a specific concert hall...) in real-time and to choose the localization of their listener's point of view.

This setup would constitute an invaluable tool for recreation of artistic and innovating practices. I am for instance referring to the project Ars musica 3D (Papal Palace of Avignon), which aims at restoring the conditions of creation in the pontifical chapel of Avignon during the XIV century: a way to link the ancient to the modern. The projectwill seek above all to recreate an environmental soundscape in order to stimulate the interpreter and provide him/her with the means to reveal the possible deployment of their musical gestures, or to grasp for instance what the ear of the cantor would perceive at the time of its execution. Placing a musical work in its "eco-logical" context undoubtedly implies research as well as interpretation, and, therefore, a part of creation. From an epistemological point of view indeed, trust in artistic taste (over a desire for an imagined authenticity) seems today a valid approach in many ways.

The setup should therefore serve musicians and researchers in two different ways:

- Avignon's Palais des Papes as a museum: To reconstitute the sound space of the pontifical chapel, and recreating an extract from an office of polyphonic mass in the time of Clement VI (c. 1352), with the help of binaural 3D acoustic emulation techniques, and to simulate, inside the Palais des Papes, a historically informed performance to be diffused by an audio system (binaural 3D helmet) adapting to the situation of the visitor in space.

\footnotetext{
${ }^{4}$ http://www.pianoandco.fr/spip.php?page $=$ mediaid $_{a}$ rticle $=137$ id $_{d}$ ocument $=392$
} 
- Interpretive: MPHS (Musical Performance in Historical Soundscape: To enable artists to confront, while practicing in a recoding studio, their musical repertoire with the original acoustics associated to a chosen edifice (St Mark's Basilica, or any specific concert hall...) in real-time and to choose the localization of their listener's point of view. The acoustic simulation becomes here a recording/rehearsal tool, as a recording device in the studio that allows for the total immersion of the musicians in a real-time virtual 3D sound space.

For a plausible result, the recording of musicians must be realized in silence, in a neutral studio, with as little reflections as possible (as in an anechoic chamber). Each singer must be equipped with helmet headphones that instantly returns the digital processing, in order to feel immersed in the virtual space. However, we will surely find ourselves faced with a cultural and technical problem: wearing helmet headphones disturbs the way the singers traditionally listen to each other and to their own voice, in a repertoire that was not conceived for amplification. The "singing body" 5 has a crucial impact on the way the singer projects his voice, and the simulation of virtual space could be of tremendous help for guiding his interpretation. The objective is to allow any musician or ensemble to be able to test, evaluate the conditions of performance of a musical production in its original sonic environment. This setup could inform early music musicians as well as open wide range of experiments for contemporary artists. The project is interdisciplinary in essence, and proposes to interrogate the above-mentioned repertoires in an original way. In line with the work undertaken since Schafer, but also on reconstructed soundscapes (ReViSMartin, Cubiculum Musicae, Bretez Project), we propose to exploit the possibilities offered by new sound technologies to recreate an immersive virtual space in three dimensions. The notion of increased perception is at the heart of this approach, in which the reconstitution of musical gestures is be prompted by virtual acoustic spaces of a new kind. Our approach seeks above all to give the performers the means to experiment with the multiple possible realisations of their own musical gestures, in order to perceive for instance which type of aural feedback the medieval cantor was interacting with, but also to place a musical work in its eco-logical context of origin, and thus stimulate new and original forms of research-creation.

Acknowledgments. We are grateful to Jonathan Bell for his French-English translation.

\section{References}

1. A. GASTOUE, La Musique en Avignon et dans le comtat du XIVe au XVIIIe siécle, R. M. Italiana, Ed., Roma, 1904, vol. XI.

\footnotetext{
${ }^{5}$ Christine Esclapez, Les "univers locaux" de Francisco Lòpez. Images in-temporelles du temps, in filigrane Mai 2015. Available at: http://revues.mshparisnord.org/filigrane/index.php?id=680
} 
2. S. ZINC, Irony and Sound : The music Maurice Ravel, university rochester press ed., 2009.

3. F. Poulenc, Poulenc au Moyen Age, Paris, P. E. (CD), Ed., Cucuron, France, 2015, no. PAR 69.

4. F. POULENC, J'écris ce qui me chante: Textes et entretiens réunis, présents et annotés par Nicolas Southons, fayard ed., Paris, 2011.

5. W. LANDOWSKA, Musique ancienne : le mépris pour les anciens - la force de la sonorité - le style - l'interprétation - les virtuoses - les Mécènes et la Musique, ivrea-édition ed., M. Senart, Ed., Paris, 1996.

6. E. KOTTOCK, A History of the Harpsichord, indiana university press ed., 2016, vol. 1.

7. EIGELDINGER, Wanda Landowska et la renaissance de la musique ancienne, actes sud ed., Arles, 2010.

8. M. FAURE, Le néoclassicisme musical, une esthétique de crise? L'influence de la socitie sur la musique, l'harmattan ed., Paris, 2008.

9. H. MESCHONNIC, Modernité-Modernité, folio essais ed., Paris, 2005.

10. N. HARNONCOURT, Le discours musical, gallimard ed., Paris, 1984.

11. F. ESCAL, Espaces sociaux, espaces musicaux, payot ed., Paris, 1979.

12. C. LAWSON, The historical perfomance of music : an introduction, cambridge university press ed., R. STOWELL, Ed., Cambridge, 1999.

13. J.-P. NAJARRO, "Jean-sébastien bach : deux œuvres au fil du temps," Inharmoniques : musique et authenticités, 1991.

14. B. VECCHIONE, Une poétique du motet médiéval : Textes, hypotextes et niveaux de discours dans l'Ave regina celorum / Tenor [Joseph ]/ Mater innocencie de Marchetto da Padova, lim ed., F. d. Actes du Colloque de Certaldo Ziino, A. Zimei, Ed., Lucca, 2009, 2013.

15. A. GUERBER, Mille Bonjours, chansons de Guillaume Dufay, alpha ed. Ensemble Diabolus in Musica (CD), 2007, no. 116. 